DE DE GRUYTER OPEN

\section{Research Article}

(C) 2018 Adisa Bala This is an open access article licensed under the Creative Commons Attribution-NonCommercial-NoDerivs License (http://creativecommons.org/licenses/by-nc-nd/3.0/).

\title{
Integration of Local Government through Administrative -Territorial Reform in Albania
}

\author{
Adisa Bala \\ PhD Candidate, Department of Management, \\ Faculty of Economy, University of Tirana; \\ Ministry of Internal Affairs, Albania
}

Doi: 10.2478/ajis-2018-0038

\begin{abstract}
There have been made many significant steps toward implementing reforms which lead Albanian Government to a consolidated integration process. Many challenges and obstacles have hindered this path, particularly those of a political nature, to which my country is still very sensitive. A kind of "hot spot" in all this discussion appeared to be the newest reform called "administrative territorial reform" or "decentralization process" which has already been implemented in 2015. Amongst the range of studies, consultations and amalgamate process in multi level governance,the concept of integration has been isolated from the perspective of European integration. The Albanian Government has undertaken this reform with the ad-hoc Parliamentary Committee in close coordination and cooperation with the local government units, funded by the STAR Project (Support to Territorial and Administrative Reform) and implemented by the United Nations Development Programme (UNDP). Despite this, there is not much evidence of a deeper cooperation to determine an integrated package of principles whereby local government authorities reflect realistic concerns about EU's influence along their mission and activities. This paper intends to explore whether the implementation of this administrative-territorial reform has taken into consideration the formal set up of EU integration, or has at least established the necessary legal, financial, cultural environment with the overall aim to enable European frameworks and processes even in local authorities and communities.
\end{abstract}

Keywords: Local Government, European Integration, Europeanisation, Administrative-Territorial Reform, Public Administration

\section{Theoretical Considerations of EU Integration in Local Governance}

After the signing of the European Charter of Municipal Liberties in 1953, a lot has been done with the aim of ridimensioning local governance, particularly when local and regional authorities had to adapt a new political and economic context because of the financial crisis of 2008. Europeanisation theory has attempted to suppose the impact of the EU on the member states.

Many reforms and administrative modifications have been made concerning the practices of governments, often initiated by the need of local governments for more authonomy.

Beginning with budget restrictions, there was a tendence of national governments to centralize few competencies, as well as the policies to weaken the freedom of local and regional authorities. In relation to the study of local government Europeanisation encloses a range of different meanings within the academic literature. Europeanisation is described as a new field, after the integration theory. Europeanisation in political science that implicates the approach to being more European. One of the earliest definitions is by Ladrech (1994) who explains Europeanisation as "an incremental process of re-orienting the direction and shape of politics to the extent that EC political and economic dynamics become part of the organisational logic of national politics and 
policy making".

Radaelli made another significant definition that we must consider, who describes Europeanisation as "a process involving, a) construction, b) diffusion and c) institutionalisation of formal and informal rules, procedures, policy paradigms, styles, 'ways of doing things' and shared beliefs and norms which are first defined and consolidated in the EU policy process and then incorporated in the logic of domestic (national and subnational) discourse, political structures and public choices " As Börzel states in an article trying to link bottom-up and top-down processes, examines states strategies to the EU level through the policy making process, if once they have been adopted at the EU level and require implementation in national policy systems. Börzel's studies shows clearly that integration processes and Europeanisation processes can not be divided into separated categories. The major areas related to local governments include economic legislation of trade market, environmental law, and regional policy. The study of integration from a local government perspective benefits by analyzing how new shifts of integration are pushed by local actors instead how local governments drive this process. Council of Europe and its Congress of Local and Regional Authorities is the "head" of expertise and a significant support of institutional activities, whose expertise has been in years the sole leader to European local and regional authorities. In this article the purpose then is to explore in particular what kind of impact the territorial reform have had on the autonomy local and regional levels of Albania in the integration aspect. It is important to see that the integration process is not only a factor that influences the position and the role of local actors through different intermediators, but also a process affecting the autonomy of local government by redistributing the power. The impact of integration regarding to the levels it spreads must be consider in three levels, from which we can understand the process: the macro level concerning to the political/economic/social structures under EU relationship, the middle level of institutional processes or inter-organizational negotiations, development strategies ect. And the third level is the micro level within municipalities itselves. Although reforms involving territorial reorganisations are already common indispensable in Europe, they are just carried out as mergers of municipalities or regionalisation and readministration. This kind of movement, based on the concept of a Europe of regions, began in the 1980s and 1990s and only after 2000s could take its real shape in many countries. The target is not anymore only to progress in decentralization, but especially the adjustment of budgetary restrictions imposed by central government eventhough they are delegating many functions and services. This is being as paradoxal as inefficient and impinging self autonomy of local government.

\section{Administrative and Territorial Reform, a Step Towards Integration}

Reforms involving territorial reorganisations are already common in Europe, by carrying out as mergers of municipalities or regionalisation of the territory. The main objective is minimizing economic and socio inequalities between LGUs. But territorial reforms have taken some other specific local conditions into account when adopting priorities, strategies and actions. To be called successful, this kind of reform has to focus on long term development from an overall European perspective, but also to walk in parallel with other reforms in the country where they are being implemented. Legislative developments are the result of strategy for further integration and the main step handling this objective or the preconditions for accession to the European Union. In almost all of the European states, municipality is the basic territorial level. However many territorial reforms have been formulated as a number reduction in units and expenditures in the name of request for better management of local public services As mentioned above in the theoretical considerations, one of the three major fields in integration target is economy. Municipalities achieve somehow economies of scale through the help of local units cooperation, often pushed by the central government in order to increase efficiency. In this means central govenrments reduce their financial transfers and assistance to the,local and regional authorities and conceive new practices. Accordingly these trends move with other reorganisations of services and these limits are sometimes prescribed by law. Following the reform there will be:

- Adoption of a constitutional law promoting inter-municipal cooperation

- Incentives to encourage the pooling of inter-municipal resources 
- Programmes to reduce costs, foster innovation and modernise public administration

- More capacity to provide a wider range of functions

- More effective planning and economic development policies

- Promoting local democracy and seeking to comply with the European principles without skipping the principles of self-government.

If municipalities implement the necessary EU policies, would have a good chance in the success of the integration process.

\begin{abstract}
Multilevel governance is not simply a question of translating European or national objectives into local or regional action, but must also be understood as a process for integrating the objectives of local and regional authorities within the strategies of the European Union. Moreover, multilevel governance should reinforce and shape the responsibilities of local and regional authorities at national level and encourage their participation in the coordination of European policy, in this way helping to design and implement Community policies
\end{abstract}

European integration affects many relations between different territorial and administrative levels by strengthening the existing structures, by giving boost to potential partnerships and by establishing a new framework of governance regulations.

\title{
3. Considerations on Reform Development in Albania
}

The administrative and territorial reform is identified as one of the key priorities of the Government and aimed to improve the quality of local public services by increasing their efficiency and also the access of citizens to local public services. The development and implementation of the administrative and territorial reform is based and conceived pursuant to the following legal framework:

- Constitution of the Republic of Albania;

- European Charter of Local Self-Government;

- Law no. 8652, dated 31/07/2000 "On the organisation and functioning of local government in

- Albania";

- Law no. 8653 , dated 31/07/2000 "On the administrative-territorial division in the Republic of

- Albania"

- Decision of the Council of Ministers (DCM) no. 1012, dated 22/11/2013 "On defining the scope of state responsibilities of the Minister of State for Local Government";

- Recommendation of the Committee of Ministers of the European Council REC(2004) "On

- the processes of reform of boundaries and/or structure of local and regional authorities".

Changes introduced as the result of the amalgamation process as stipulated by the draft law amending the Law no.8652, dated 31.07.2000 on "Functioning and organization of the local government" are:

- Communes stopped existing;

- Introduction of Administration Units;

- Changes to existing roles of the Municipal Council and Mayor;

- Introduction of Administrators;

- The Administrative Units are considered public service offices;

- The organic structure of the Administrative Units, are part of the organic structure of the New Municipality;

- The administration of the Administrative Unit supports the activities of the competent structures of the New Municipality;

- Changes how the work is executed and distributed in delivering the public services and horizontal functions, to help in improving the effectiveness and efficiency of service delivery.

Organisations such as the Council of Europe (CoE), Organisation for Security and 
Cooperation in Europe (OSCE), U.S. Agency for International Development (USAID), Swedish International Development Cooperation Agency (SIDA), Swiss Agency for Development and Cooperation (SDC), Austrian Development Agency (ADA), United Nations Development Program (UNDP) have given their technical and financial support to have the best analyse the situation and develop alternatives based on the best criteria for a new administrative and territorial division. A series of studies performed by international and Albanian organizations or institutions have been conducted, and they have recommended specific proposals regarding the criteria and alternatives to be used in developing the territorial reform in Albania.

\section{Conclusion}

This paper attempted to present a perspective of European integration from a local government perspective and if this perspective is being considered when a new organization in the form of territorial reform is planned and implemented. As the EU's legal, financial and political impact conducts to impressment in order to influence EU policies, Europeanisation has fostered into European integration. The impact of cooperation has modified many of EU policies, which was concretized through the formal recognition in the Lisbon Treaty, also by the long course of assistance in regional level.

However, these initiatives are not enough and the responsability to the local level as well has to be pursued beyond formal arrangements, if effective changes are expected in practice. On the other side a very few local actors (i.e agencies) settle down to European affairs and municipal issues are still away from the focus. Policy making is still crucial in design and implementation of EU policies in local level and still weak, because local actors face political resistance from central authorities. Local actors are excluded from most major decisions in drafting and developing strategies, without keeping in mind the fact that every development's root are in local levels and should not be limited. Referring these assumptions and the real facts of the situation the study of European integration from a local government perspective should be more interactive and shared in cooperation into multiple levels of government. Only such kind of access will ensure a comprehensive involvement and benefits of the public.

\section{Reference}

Benz, Arthur, and Eberlin, Burkhard. 1999. "The Europeanization of regional policies: patterns of multi-level governance," Journal of European Public Policy, 6

Börzel, Tanja \& Thomas Risse, 2000, When Europe Hits Home - Europeanisation and Domestic Change, in European Integration online Papers.

Committee of the Regions. 2009. The Committee of the Regions' White paper on Multilevel Governance.

European Integration and Local Government, 1997 EE Publishing

Marius Guderjan, "Local Government and European integration - beyond Europeanisation?" , Political Perspectives 2012,

Michelle Cini, European Union Politics 2nd Edition (Oxford: Oxford University Press, 2007) p. 407

Technical criteria for the new administrative and territorial division (Minister of State for Local Government ,April 2014)

www.reformaterritoriale.al

www.ccre.org

www.gadc.org.al

www.dldp.al 